\title{
Evaluation of Tree Species Composition for Sustainable Eco-Tourism Development of Maladumba Lake and Forest Reserve, Bauchi-Nigeria
}

\author{
Ibrahim Umar, Lamido Auwal, Ali Zakari, Ibrahim Fatima, Yahaya Umar Kubura, \\ and Justina Talatu Dibilang
}

\section{ABSTRACT}

Ecotourism refers to travelling to relatively undisturbed or uncontaminated natural areas, such as protected areas, with the aim of studying, admiring, and enjoying the scenery and the faunal and floral composition along with its existing cultural aspects. This paper evaluated Tree species composition of Maladumba Lake and Forest Reserve, BauchiNigeria for sustainable eco-tourism development. Wandering quarter method of vegetation analysis was employed for the study where five sampling sites were studied to determine species richness, percentage frequency, basal area, relative density, relative dominance, importance value indices, mean distance between trees, mean area of trees and number of individual stem per hectare of tree species encountered. Results obtained indicated total of eighteen different Tree species in the protected area with Mitragyna inermis $(126732.9 \mathrm{~cm})$, Adansonia digitata $(31714.9 \mathrm{~cm})$, Balanites aegyptiaca $(29727.3 \mathrm{~cm})$, and Piliostigma thonningii $(28697.7 \mathrm{~cm})$ as species with the highest basal area. While Funtumia elastica presented the highest frequency of occurrence $(80 \%)$ followed by Acacia nilotica, Anogeissus leiocarpus, Balanites aegyptiaca and Cassia singueeana with $60 \%$ each. Relative densities of Mitragyna inermis (18.1\%) stood as the highest, followed by Funtumia elastica $(16.6 \%)$ and Balanites aegyptiaca $(12.5 \%)$. Relative dominance suggested Mitragyna inermis $(18.1 \%)$ with the highest value seconded by Adansoni digitata (12.4\%) and Balanites aegyptiaca (11.7\%). Mitragyna inermis (49.8) had the highest IVI followed by Balanites aegyptiaca (24.4) then Piliostigma thonningii (11.7). Very low values of mean distance between trees $(6.9 \mathrm{~m})$, mean area occupied by individual trees $(47.6 \mathrm{~m})$, and density of trees per hectare (210) suggested sparsely populated vegetation cover in the protected area. It was concluded that Maladumba Lake and Forest Reserve is under serious deforestation. As an Ecotourism attraction, serious reforestation program was recommended to salvage the situation before the whole protected lose its value.

Keywords: Ecotourism; Deforestation; Protected Area; Vegetation.
Published Online: February 3, 2021

ISSN: 2684-5199

DOI:10.24018/ejbio.2021.2.1.141

Ibrahim Umar*

Biology Education Department. School of Science Education, Federal College of Education (Tech.), Nigeria.

(e-mail: golobom@yahoo.co.uk)

Lamido Auwalu

School of Science and Technology,

Abubakar Tatari Ali Polytechnic, Nigeria.

(e-mail: auwalulamido2@gmail.com)

Ali Zakari

Biology Education Department. School of Science Education, Federal College of

Education (Tech.), Nigeria.

(e-mail: alizakari5@gmail.com)

Ibrahim Fatima

Biology Education Department. School of Science Education, Federal College of Education (Tech.), Nigeria.

(e-mail: fatiiabdulkarim@gmail.com)

Yahaya Umar Kubura

Biology Education Department. School of Science Education, Federal College of Education (Tech.), Nigeria.

(e-mail: kubrayahaya8@gmail.com)

Talatu Dibilang Justina

Biology Education Department. School of Science Education, Federal College of Education (Tech.), Nigeria.

(e-mail: dibilangjustina ${ }^{@}$ gmail.com)

*Corresponding Author

\section{INTRODUCTION}

Ecotourism is a term which refers to travelling to relatively undisturbed or uncontaminated natural areas with the aim of studying, admiring, and enjoying the scenery and the faunal and floral composition along with its existing cultural aspects [1]. Ecotourism can also be to put as travelling to fragile, pristine, and usually protected areas, such as Maladumba Lake and Forest Reserve (MLFR), aimed at directly benefiting economic development and political empowerment of local communities that fosters respect for different cultures [2]. It helps in educating the traveler while on the other hand, provides funds for conservation. Ecotourism is a sustainable, non-invasive form of nature-based tourism that focuses primarily on learning about nature first-hand It typically occurs in natural areas and should contribute to the conservation of such areas [2].

From the above definitions, it can be deduced that ecotourism involves natural areas, such as MLFR with the aim of learning on the part of the tourist, and conservation on the aspect of natural resources. Eco-tourism is one of the fastest growing industries in the world today. It is a form of natural resource-based tourism focused on experiencing and learning about nature. The term ecotourism can be well described with the following five criteria: nature conservation, low impact, sustainability, meaningful community involvement, and environmental education [2].

The term sustainable development, as put by Brundtland Report, was defined as a development that meets the needs of the present without compromising the ability of future generations to meet their own needs [3]. Thus, the ecotourism use of MLFR is geared towards a sustainable 
development of that protected area without compromising the stability of the ecosystem.

Protected area, such as MLFR, is defined as a clearly designated geographical space, recognized, dedicated and managed, through legal or other effective means, to achieve the long term conservation of nature with associated ecosystem services and cultural values [4].

\section{MATERIALS AND METHODS}

\section{A. Study Area}

Maladumba Lake and Forest Reserve is located in Maladumba-Misau, Misau Local Government Area of Bauchi State. It is approximately $18 \mathrm{~km}$ South-West of Misau town, in Bauchi State (Fig. 1). It has an area of approximately $120 \mathrm{~km}^{2}$ [5]. It has a Sudan type of climate, with two distinct seasons; a short, wet season that span across May-September and a longer dry season from October-April. Its average annual rainfall is about $800 \mathrm{~mm}$ with a unimodal distribution during the rainy season. July and August marks the highest peak of the wet season and the rainfall is characterized by storm with high intensity. Mean temperature ranges from $26-34{ }^{\circ} \mathrm{C}$ during the hot months of April and May. The dry season is dominated by dusty, north easterly Harmattan winds [5]. MLFR lies on sedimentary rocks of the Kerri Kerri Formation. The Formation comprises lacustrine and deltaic-type sediments of Paleocene age deposited on the Basement Complex to a thickness of up to $200 \mathrm{~m}$. The formation is predominantly erinaceous, consisting of loosely cemented sands and grits, clayey sandstones, massive clays and silts. Bands of ironstone and conglomerate occur locally. The formation thins towards its surface unconformity with the Basement Complex in the area west of the lake. In this area, the River Jimin, the main tributary of the Kari River, has incised through the formation to flow on crystalline rocks of the Basement Complex. The soils in the area are deep sandy clay and loamy sands [6].

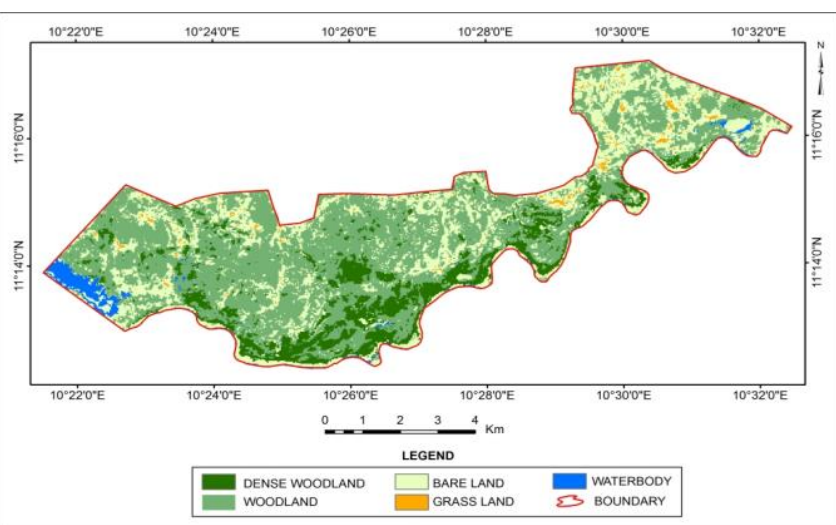

Fig. 1. Geographical layout and vegetation types of the Maladumba Lake and Forest Reserve (MLFR) in Bauchi state, North-east Nigeria [8].

Vegetation of MLFR is the Sudan Savannah vegetation type which is characterized by open deciduous woodland with common species such as Isoberlinia doka, Anogeissus leiocarpus, Balanites spp. and Combretum spp. The region has been much affected by clearance for agriculture, fire and cutting for wood and charcoal. Most of the remaining natural habitat is found only in the protected area, but there are larger blocks of relatively intact vegetation in the Eastern part of the zone. There are gallery forests along rivers and grasslands often dominated by Hyparrhenia (Elephant grass) that stand up to 3-4 $\mathrm{m}$ in height [7].

\section{B. Method for Data Collection}

Wandering quarter method of vegetation analysis [9] was adopted for quantitative data generation in this study. It is a method of sampling plant community using plotless survey technique whereby a researcher obtain data on a community by zig-zag movement from one tree to another heading in the same general compass direction [9]. Five sampling points were randomly selected (four angles and center) in the protected area (PA). The procedure for collecting data was as follows:

a) Starting point was randomly selected avoiding edge of vegetation. A compass line (Imaginary line) was then selected from the starting point that led into the stands of the trees to be studied.

b) While standing at the starting point and sighting within an angle of $90^{\circ}$, $\left(45^{\circ}\right.$ on either side of the general compass line) the nearest tree (of not less than $10 \mathrm{~cm}$ circumference) whose center lies within the inclusion angle was considered the first sampled tree.

c) The species name was determined using dichotomous key. In case of failure to properly name the species encountered, sample of leaves, flowers and fruits (where found) was collected and taken to Abubakar Tafawa Balewa University Bauchi herbarium for identification.

d) Circumference (in $\mathrm{cm}$ ) at breast height ( $\mathrm{cbh}$ ) of the tree; and distance from the starting point to the tree were also recorded.

e) From the first tree sampled, sighting along the compass line again, the second nearest tree within the $90^{\circ}$ inclusion angle was determined. The same parameters were again recorded.

f) Step five was repeated severally thereby wandering about until $100 \mathrm{~m}$ of distance was covered while maintaining the same general compass direction.

Data collected were used to calculate several common measures of plant community structure including, species richness, relative basal area, stem per hectare, mean distance between trees, mean area of trees, relative density, relative dominance, and importance value index (IVI) of tree species.

\section{Method of Data Analysis}

Data from wandering quarter method was used to calculate the following in each of the five plots sampled:

i) Relative Density, which was the number of individuals of a species divided by total number of trees counted, multiplied by 100 .

ii) Percentage Frequency, which was the number of points a species occurred divided by total number of points sampled, multiplied by 100 .

iii) Basal area of each tree was equal to $\pi(r)^{2}$ where ' $r$ ' equals to circumference at breast height divided by $2 \pi$.

iv) Relative dominance was basal area per species divided by the total basal area of all species multiplied by 100 .

v) IVI was the relative density plus the relative dominance. 
vi) The mean distance $\left(d_{m}\right)$ between trees (in metres); this was the sum of all distances divided by the number of distance measurements

vii) The mean area (MA) of all trees was $\left(\mathrm{d}_{\mathrm{m}}\right)^{2}$.

viii) Density (D) of all trees (in trunk) per unit area was ' $A$ ' divided by 'MA' (where $A=$ unit area i.e., a hectare, which is $10,000 \mathrm{~m}^{2}$; thus $\mathrm{D}=10,000 \mathrm{~m}^{2}$ divided by MA which gives density of trees in trunk per hectare).

\section{A. Species Richness}

Table one below presented species richness of the protected area (PA). Total of 18 different species were identified in the PA, which suggest very low species available in the PA. This factor may be attributed to the high encroachment reported in that protected from 19952015 [8]. A lot of human activities were observed in the PA that has turn it into almost uncultivated farm land.

TABLE 1: TREE SPECIES RICHNESS OF MALADUMBA LAKE AND FOREST

\begin{tabular}{|c|c|c|}
\hline \multicolumn{3}{|c|}{ RESERVE (MLFR) } \\
\hline No & Species & Family \\
\hline 1 & Acacia nilotica(L.) Willd. Ex Delile & Mimosoideae \\
\hline 2 & Adansonia digitata $\mathrm{L}$ & Malvaceae \\
\hline 3 & Anogeissus leiocarpus (DC.) Guill. \&Perr. & Combretacea \\
\hline 4 & Balanites aegyptiaca (L.) Delile & Zygophyllaceae \\
\hline 5 & Bombax costatum Pellegr. \&Vuillet. & Malvaceae \\
\hline 6 & Cassia singueeana (Del.) Lock & Fabaceae \\
\hline 7 & Catunaregem nilotica (stapf.) Tirveng. & Rubiaceae \\
\hline 8 & Combretum molle R.Br. ex G.Don & Combretaceae \\
\hline 9 & Combretum nigricans lepr. & Combretaceae \\
\hline 10 & Diospyros mespliformis Hochst. & Ebenaceae \\
\hline 11 & Feretia apodanthera Del. & Rubiaceae \\
\hline 12 & Funtumia elastica (Preuss) Stapf & Apocynaceae \\
\hline 13 & Mitragyna inermis (Wild.) Kuntze & Rubiaceae \\
\hline 14 & Piliostigma thonningii Schumach. & Fabaceae \\
\hline 15 & Streospermum kunthianum Chamn & Bignoniaceae \\
\hline 16 & Terminalia ivorensis A. Chev & Combretaceae \\
\hline 17 & Ziziphus abyssinica A. Rich. & Rhamnaceae \\
\hline 18 & Ziziphus spina-christi (L.) Desf. & Rhamnaceae \\
\hline
\end{tabular}

\section{B. Basal Area and Percentage Frequency of Species}

Table 2 presented Mitragyna inermis (126732.9 cm), Adansonia digitata $(31714.9 \mathrm{~cm})$, Balanites aegyptiaca $(29727.3 \mathrm{~cm})$, and Piliostigma thonningii $(28697.7 \mathrm{~cm})$ as species wih the highest basal area. This implies that these are species with biggest trunk in the PA. Because Mitragyna is a shrub but can grow up to sixteen meters as a tree when in damp and perennially flooded sites, swampy Savannah or at inland side of coastal mangrove swamp. MLFR supported this condition which may be the reason for the success of this species in this PA. Adansonia digitata on its part is known for its vegetable purpose as source of local soup. Its high basal area record can be ascribed to its preservation for local purpose over long period of time in the area. Balanites which is referred to as desert date, is a slow growing evergreen or semi-deciduous, multi-branched, spiny shrub or tree with variety of habitats but grow best in low-lying level alluvial sites with deep sandy loam and uninterrupted access to water such as valley floors, river banks or the foot of rocky slopes. These attributes fit MLFR, thus may the reason for its success in this area. Piliostigma is a fast-growing evergreen shrub that does well in evanescent vegetation. It results as species in secondary growth on abandoned cultivated land like MLFR which is so fast looking as abandoned cultivated land due to high level of encroachment into the PA. Therefore, this species became favoured and indicated high record of basal area. Results on percentage frequency, however, presented Funtumia elastica with the highest frequency of occurrence (80\%) while Acacia nilotica, Anogeissus leiocarpus, Balanites aegyptiaca and Cassia singueeana with $0 \%$ each. The lead by Funtumia elastica can be ascribed to its biology; a West African rubber tree that is fast-growing, evergreen tree growing up to 30 meters tall especially in waterlogged habitat. The environment of MLFR must have favoured its proliferation and success in the PA.

TABLE 2: Basal Area And Percentage Frequency of Species in

\begin{tabular}{lcc}
\multicolumn{1}{c}{ Species } & $\begin{array}{c}\text { Basal Area } \\
(\mathrm{cm})\end{array}$ & Frequency, \% \\
\hline Acacia nilotica (L.) Willd. Ex Delile & 2568.5 & 60 \\
Adansonia digitata L. & 31714.9 & 20 \\
Anogeissus leiocarpus (DC.) Guill. \& & 24371.4 & 60 \\
Perr. & 29727.3 & 60 \\
Balanites aegyptiaca (L.) Delile & 793.8 & 20 \\
Bombax costatum Pellegr. \&Vuillet. & 2090.0 & 60 \\
Cassia singueeana (Del.) Lock & 105.5 & 20 \\
Catunaregem nilotica (stapf.) & 1006.0 & 40 \\
Tirveng. & 69.4 & 20 \\
Combretum molle R.Br. ex G.Don & 678.5 & 40 \\
Combretum nigricans lepr. & 149.5 & 20 \\
Diospyros mespliformis Hochst. & 3715.9 & 80 \\
Feretia apodanthera Del. & 126732.9 & 40 \\
Funtumia elastica (Preuss) Stapf & 28697.7 & 40 \\
Mitragyna inermis (Wild.) Kuntze & 55.3 & 20 \\
Piliostigma thonningii Schumach. & 715.9 & 40 \\
Streospermum kunthianum Chamn & 153.9 & 40 \\
Terminalia ivorensis A. Chev & 1193.8 & 20 \\
Ziziphus abyssinica A. Rich. & & \\
Ziziphus spina-christi (L.) Desf. &
\end{tabular}

\section{Relative Density, Relative Dominance and Importance Value Indices}

Table 3 below presented relative densities of Mitragyna inermis $(18.1 \%)$ as the highest, followed by Funtumia elastica $(16.6 \%)$ and Balanites aegyptiaca (12.5\%). This signifies that they are the species that are more concentrated within the PA in the order of magnitude as presented by the result. The measures on relative dominance on the other hand suggested Mitragyna inermis $(18.1 \%)$ as the species with the highest value seconded by Adansoni digitata $(12.4 \%)$ and Balanites aegyptiaca $(11.7 \%)$. This result suggested that in terms of trunk size of all species studied, these species indicated dominance in the order presented. But the overall importance value for the species, the result showed Mitragyna inermis (49.8) as the most successful species in the PA, followed by Balanites aegyptiaca (24.4) then Piliostigma thonningii (11.7).

D. Mean Distance between Trees (m), Mean Area Occupied by a Tree $\left(\mathrm{m}^{2}\right)$ and Mean Density of Trees per Hectare in MLFR

Table 4 below showed results on mean distance between trees as $6.9 \mathrm{~m}$ at the studied PA. This is an indication of very high deforestation in that PA as compared to findings in Gashaka-Gumti National Park $(.4 \mathrm{~m})$ and Kanawa Forest Reserve $(.7 \mathrm{~m})$ [8]. The value on mean area occupied by individual trees $(47.6 \mathrm{~m})$ also suggested sparsely populated vegetation cover when compared to same study [8] where 
values of $11.6 \mathrm{~m}$ was observed in Gashaka-Gumti National Park and $13.7 \mathrm{~m}$ in Kanawa forest reserve. Result on density of trees per hectare showed 210 at the study site which clearly proved less number of trees in the PA when compared to Gashaka-Gumti and Kanawa Forest with 862 and 730 respectively [8].

TABLE 3: RELATIVE DENSITY, RELATIVE DOMINANCE AND IMPORTANCE \begin{tabular}{cccc}
\multicolumn{4}{c}{ VALUE INDICES (IVI) OF SPECIES IN MLFR } \\
\hline \multirow{2}{*}{ Species } & $\begin{array}{c}\text { Relative } \\
\text { density }\end{array}$ & $\begin{array}{c}\text { Relative } \\
\text { dominance }\end{array}$ & $\begin{array}{c}\text { Importance } \\
\text { Value Index }\end{array}$ \\
\hline
\end{tabular}

$\begin{array}{lccc}\text { Acacia nilotica } \text { (L.) Willd. Ex } & 5.5 & 1.0 & 6.5 \\ \text { Delile } & 1.4 & 12.4 & 13.8 \\ \begin{array}{l}\text { Adansonia digitata } \text { L. } \\ \text { Anogeissus leiocarpus (DC.) Guill. }\end{array} & 6.9 & 9.6 & 16.5 \\ \text { \&Perr. } & 12.5 & 11.7 & 24.4 \\ \text { Balanites aegyptiaca } \text { (L.) Delile } & 1.4 & 0.3 & 1.7 \\ \text { Bombax costatum Pellegr. } & 8.3 & 0.8 & 9.1 \\ \text { \&Vuillet. } & 1.4 & 0.0 & 1.4 \\ \text { Cassia singueeana } \text { (Del.) Lock } & 4.2 & 0.4 & 4.6 \\ \text { Catunaregem nilotica } \text { (stapf.) } & 1.4 & 0.0 & 1.4 \\ \text { Tirveng. } & 2.8 & 0.3 & 3.1 \\ \text { Combretum molle } \text { R.Br. ex G.Don } & 2.8 & 0.1 & 2.9 \\ \text { Combretum nigricans lepr. } & 16.6 & 1.4 & 18.0 \\ \text { Diospyros mespliformis } \text { Hochst. } & 18.1 & 49.8 & 67.9 \\ \text { Feretia apodanthera } \text { Del. } & 6.9 & 11.3 & 18.2 \\ \text { Funtumia elastica } \text { (Preuss) Stapf } & 1.4 & 0.0 & 1.4 \\ \text { Mitragyna inermis } \text { (Wild.) Kuntze } & 2.8 & 0.3 & 3.1 \\ \text { Piliostigma thonningii } \text { Schumach. } & 2.8 & 0.1 & 2.9 \\ \text { Streospermum } \text { kunthianum } \text { Chamn } & 2.8 & 0.5 & 3.3 \\ \text { Terminalia ivorensis A. Chev } & & & \\ \text { Ziziphus abyssinica A. Rich. } & & \end{array}$

TABLE 4: Mean Distance Between Trees (M), Mean ARea OCCuPIED BY A TREE $\left(\mathrm{M}^{2}\right)$ AND MEAN DENSITY OF TREES PER HECTARE IN MLFR

\begin{tabular}{cccc} 
BY A TREE $\left(\mathrm{M}^{2}\right)$ AND MEAN DENSITY OF TREES PER HECTARE IN MLFR \\
\hline Protected Area & $\begin{array}{c}\text { Mean } \\
\text { distance }\end{array}$ & Mean area & Mean density \\
\hline $\begin{array}{c}\text { Maladumba Lake and } \\
\text { Forest Reserve }\end{array}$ & 6.9 & 47.6 & 210 \\
\hline
\end{tabular}

\section{CONCLUSION}

Maladumba Lake and forest reserve is one of its kind in the whole of Northeast Nigeria as a protected area that has lake (aquatic ecosytem) and forest ecosystem all in one place. It so fascinating and encourages teaming tourists from far and near. However, from the foregone discussions, it logical to conclude that MLFR is under serious deforestation as indicated by the results obtained. As an Ecotourism attraction, serious measures need to be taken to salvage the situation before the whole protected lose its value.

\section{RECOMMENDATION}

The following recommendations are hereby suggested:

1. Serious reforestation program should be vigorously pursued with the aim of boosting the floristic composition of the protected area.

2. Forest guards should be employed to protect the remaining vegetation cover with immediate effect.

3. Clear boundary demarcation, through fencing if necessary, should be put in place to check against encroachment.

\section{ACKNOWLEDGEMENT}

We sincerely acknowledge the gracious permission of the Bauchi state government for allowing us conduct this research in Maladumba Lake and forest reserve. We also wish to express our gratitude to the management of the protected area for the assistance rendered to us as guide during the field data collection.

\section{REFERENCE}

[1] Weaver, D. B. (2005). Mass and Urban Ecotourism: New Manifestations of an Old Concept. Tourism Recreation Research, 30:19-26.

[2] Bayram, G. E., Ercan K., and Ali T. B. (2017). The Importance of Ecotourism Consciousness on Tour Guiding Education. Journal of Research in Education and Teaching (3) 40-50.

[3] WCED (World conference on environment and development) (1987) In: Jennifer, A.E. (2006). An introduction to sustainable development (Third edition). Routledge Tylor and Francis. London. P7-8.

[4] International Union for Conservation of Nature (2008). Threats to Forest Protected Areas: Summary of A Survey of 10 Countries Carried out in Association with the World Commission on Protected Areas 2.

[5] Abdullahi, M.B. (2012). Local Communities and Sustainable Management in Maladumba Lake and Forest Reserve Nigeria. Asian Journal of Biological Sciences, 5: 113-119.

[6] Ayeni, J.O.S., 2007. Participatory management plan of mala-dumba lake and forest reserve. Prepared for Environ-Consult and submitted to the NPSB Abuja Nigeria, pp: 94.

[7] Anonymous (2014). An IUCN situation analysis of terrestrial and freshwater fauna in West and Central Africa - Supplementary Information. Retrieved at https://portals.iucn.org/library/sites/library/files/documents/SSC-OP054-Supp.pdf on 13/04/2018.

[8] Umar, I., Hasabelrasoul F. M., Zaroug M. S. A., Abdullahi M. B., \& Babangida H. (2018). Evaluation of Management Approaches of Selected Protected Area Types in Dry Region of North-East Nigeria. World Journal of Innovative Research (WJIR), 5(6): 11-22.

[9] Kell, J.G. (2006). Measuring community structure of a forest using the wandering quarter method: in Tested Studies for Laboratory Teaching, vol. 27 (M.A. O'Donnell, Editor). Proceedings of the $27^{\text {th }}$ workshop/ conference of the association for Biology Laboratory Education (BLE). P31-46. 